\title{
THE CLINICO-PATHOLOGICAL SYNDROME PRODUCED BY CO-EXISTING PULMONARY ARTERIAL AND VENOUS HYPERTENSION
}

\author{
BY \\ DONALD HEATH, ERIC V. COX, AND J. N. HARRIS-JONES \\ From the Department of Pathology, the University of Birmingham, the General Hospital, Birmingham, \\ and the Royal Hospital, Sheffield
}

(RECEIVED FOR PUBLICATION JUNE 27, 1957)

In the last decade cardiac catheterization has demonstrated that the pressure in the pulmonary arteries and veins may greatly influence the clinical picture and prognosis in various forms of heart disease. Cases with severe pulmonary arterial hypertension show the clinico-pathological syndrome of hypertensive pulmonary vascular disease (Heath and Whitaker, 1956a). Severe pulmonary venous hypertension, following left ventricular failure due to diffuse myocardial disease, is associated with a clinical picture similar to that of constrictive pericarditis and the pathological features of pulmonary congestion and haemosiderosis. The purpose of this communication is to report the association of pulmonary arterial and venous hypertension in a case of diffuse myocardial fibrosis, a state of affairs which represents the fusion of the two main clinico-pathological pressure syndromes. The histology of the lung and the results of cardiac catheterization are described. These findings are compared and contrasted with similar observations from previously reported cases of each of the pressure syndromes. The role of a raised pressure in the pulmonary veins in the aetiology of pulmonary arterial hypertension is discussed.

\section{CASE RePort}

A man aged 22 years, known to have had diabetes mellitus for eight years, was admitted cyanosed and breathless. Five years before admission he had developed a severe unexplained anaemia with radiological evidence of pulmonary congestion from which he had made an apparently complete recovery.

On examination he had the signs of pulmonary arterial hypertension in the form of a right ventricular heave, diastolic shock, and a widely split second sound in the pulmonary area that was louder than the aortic second sound. $\mathrm{He}$ was in congestive cardiac failure, with hepatomegaly, a jugular venous pressure raised $4 \mathrm{~cm}$. at $60^{\circ}$, and exhibiting giant "a" waves and peripheral systemic oedema. The haemoglobin level was $14.8 \mathrm{~g}$. \%. An electrocardiogram showed evidence of diffuse myocardial damage. The teleradiogram was not typical of hypertensive pulmonary vascular disease in that it showed marked cardiomegaly and an uncharacteristic cardiac silhouette (Fig. 1A). A typical teleradiogram from a case of hypertensive pulmonary vascular disease is shown in Fig. 1B. There was radiographic proof of pulmonary venous hypertension in the form of hilar congestion, pulmonary oedema, and evidence of pulmonary haemosiderosis.

The results of cardiac catheterization were as follows :

Blood Pressures (Fig. 2) (mm. Hg above level of the back) Left pulmonary artery $\quad \ldots \quad \ldots \quad \ldots \quad 90 / 60$ to $80 / 50$

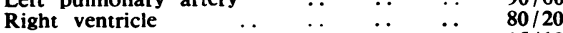

Right atrium $\ldots$ 15/10

Wedged left pulmonary capillary mean pressure .. 35

Thus pressures were high both in pulmonary arteries and in pulmonary veins.

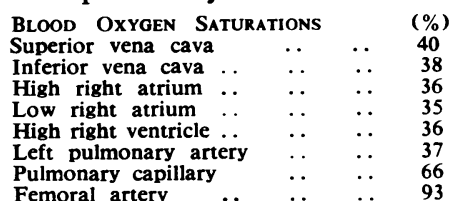

The progressive congestive cardiac failure did not respond to treatment and the patient died.

\section{NECROPSY REPORT}

The heart weighed $625 \mathrm{~g}$. The left ventricle was dilated and thinned, and, on sectioning the myocardium, about 50 areas of firm fibrous tissue were found. The right ventricle was hypertrophied. There was antemortem thrombus in both ventricles in the region of the apex. The valves and coronary arteries were normal. The left atrium was opaque. The pulmonary artery was dilated and atheromatous, but the aorta was small. The appearances were those of idiopathic diffuse myocardial fibrosis, sometimes referred to as Fiedler's myocarditis. 

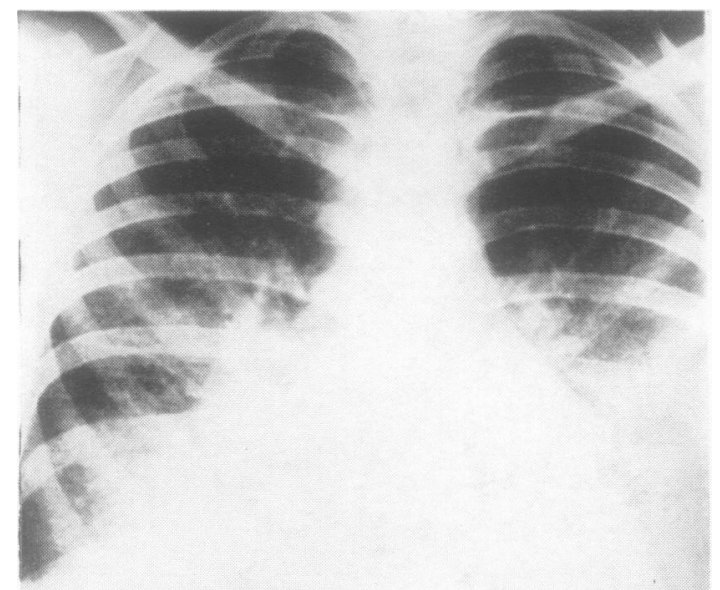

Fig. 1A

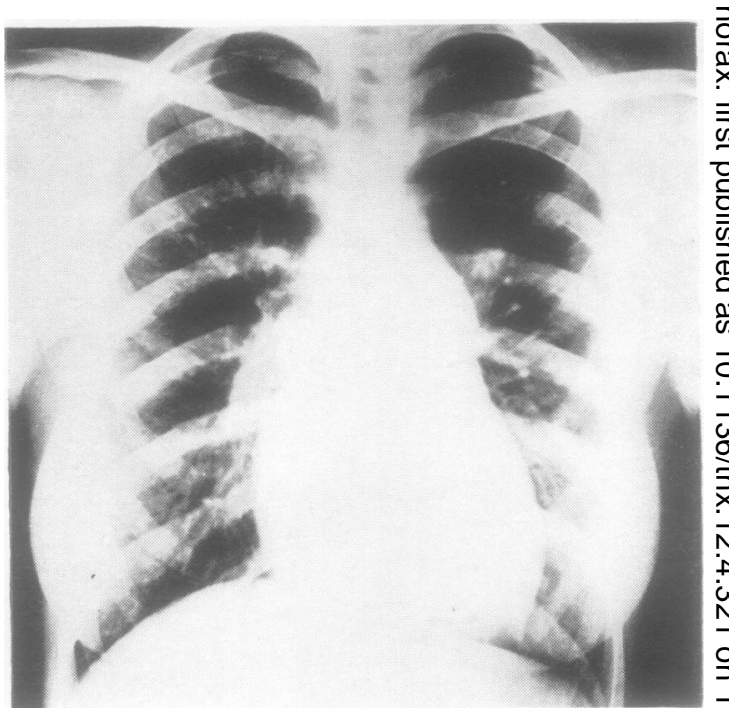

Fig. 1B

FIG. 1A.-Teleradiogram showing gross cardiac enlargement. The lung fields show congestive changes and stippling indicative of pulmonary haemosiderosis.

Fig. 1B.-Teleradiogram from a patient with ventricular septal defect and severe pulmonary hypertension to illustrate in contrast to Fig. IA the radiographic features of hypertensive pulmonary vascular disease. There is only slight cardiac enlargement with prominence of the pulmonary arteries and their main branches. The peripheral lung fields are clear.

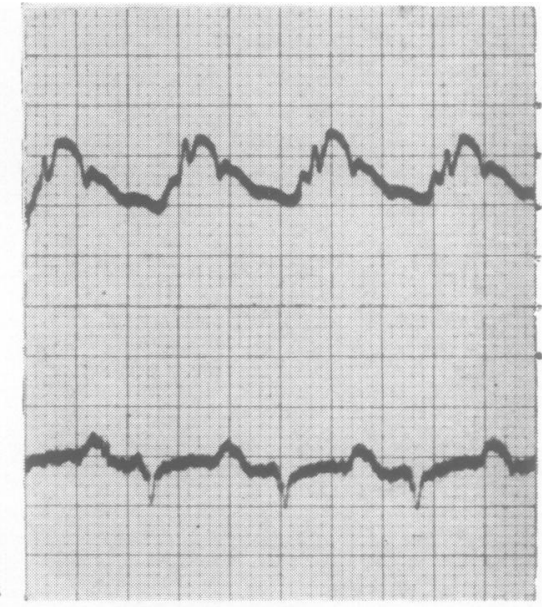

$\mathrm{mm} . \mathrm{Hg}$
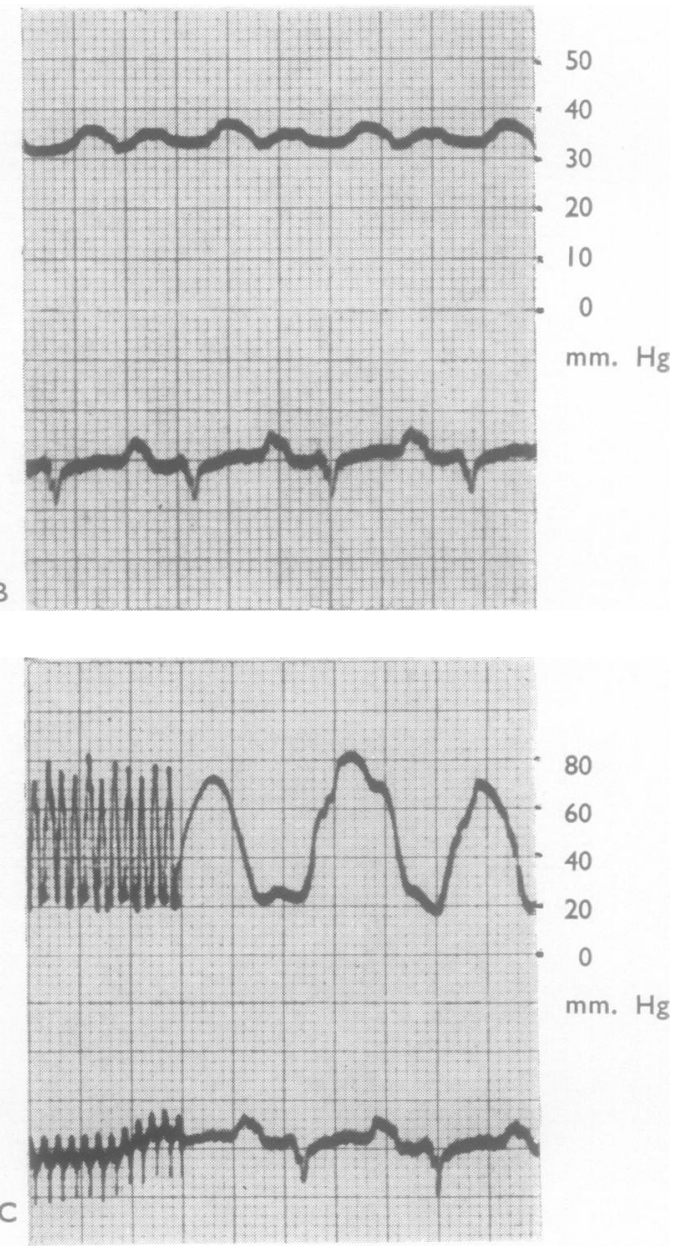

FIG. 2.-Blood pressure tracings taken at cardiac catheterization. A, Right pulmonary artery, blood pressure $88 / 60 \mathrm{~mm}$. Hg. B, Wedged pulmonary capillary blood pressure, taken to equal pulmonary venous blood pressure, varies from 32 to $38 \mathrm{~mm}$. $\mathrm{Hg}$. C, Right pulmonary artery (blood pressure $8044 \mathrm{~mm}$. Hg) to right ventricle $(80 / 20 \mathrm{~mm}$. $\mathrm{Hg})$. 
The upper and lower lobes of the left lung and the middle lobe of the right were brown and firm and showed abundant free iron due to pulmonary haemosiderosis. The appearances were those of brown induration. The mediastinal lymph nodes were plum coloured and showed free iron on testing with Perles' reagents. The small pulmonary arteries were grossly atheromatous. There was a nutmeg liver, a cricketball spleen, and congestion of the other abdominal viscera.

Histological examination of the heart showed diffuse fibrosis throughout the myocardium with a sparse chronic inflammatory reaction. The main pulmonary arteries showed atherosclerosis and numerous foci of fibrosis with loss or derangement of elastic fibrils in all but the peripheral layer of the (less than 1,000 $\mu$ in external diameter) were also media. The smaller elastic pulmonary arteries atheromatous. Measurements of the arteries were made by the technique of Best and Heath (1957).

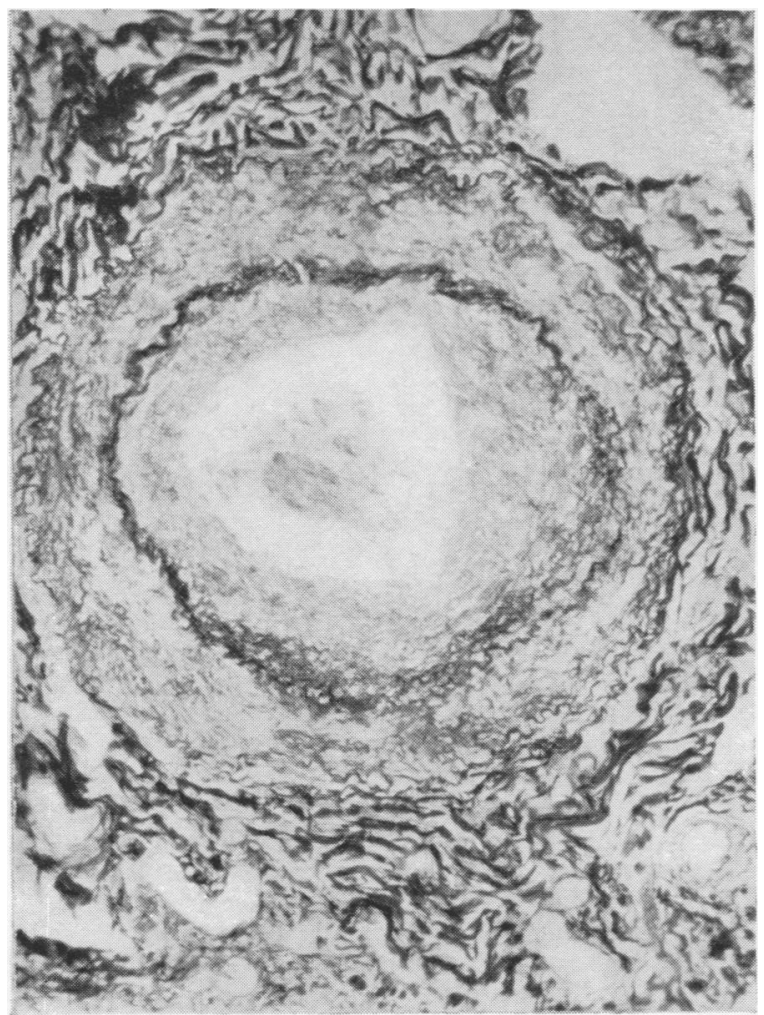

Fig. 4.-Transverse section of a muscular pulmonary artery, $560 \mu$ in diameter, showing adventitial fibrosis, medial hypertrophy, and intimal fibroelastosis, $\times 105$.

Figs. 4 and 5 are stained for elastic by the Lawson modification of the Weigert-Sheridan method to show the characteristic features of hypertensive pulmonary vascular disease.

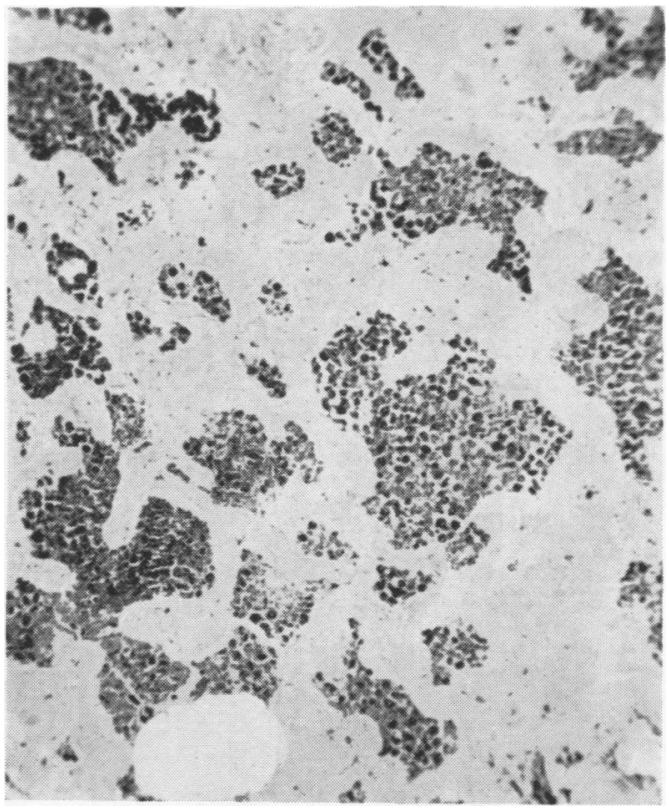

Fig. 3. Section of lung stained by Perles' reagents to demonstrate severe pulmonary haemosiderosis, a condition frequently associated with pulmonary venous hypertension, $\times 75$.

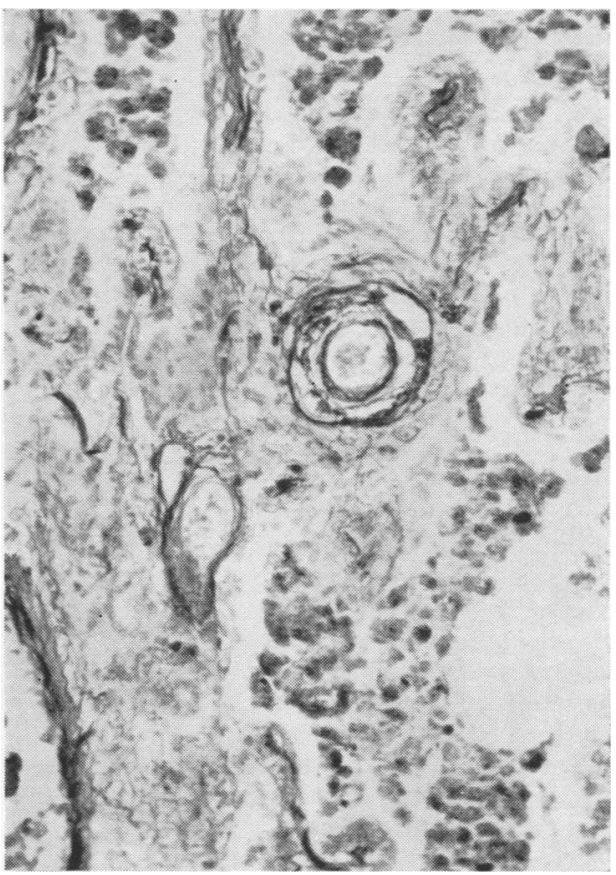

FIG. 5.-Transverse section of a pulmonary arteriole, $60 \mu$ in diameter, showing a distinct muscular media with internal and external elastic laminae. Normal arterioles are lined only by a single lamina with no muscular media, $\times 150$. 


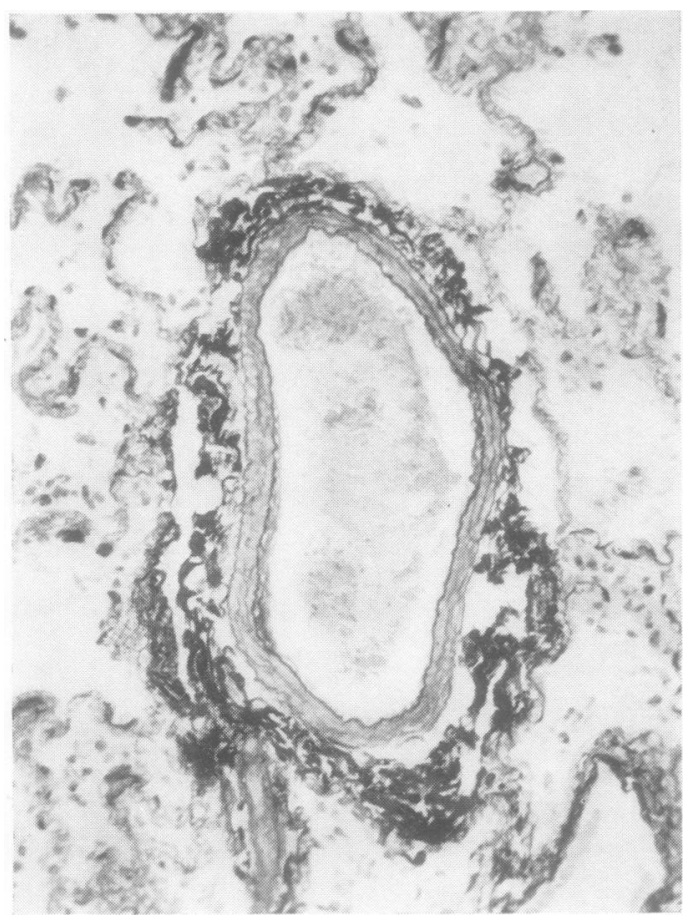

Fig. 6

There was a marked difference in the appearance of the alveoli and small pulmonary vessels between those lobes which showed brown induration and those that did not. In the lobes showing brown induration there were many intra-alveolar foci of haemosiderincontaining macrophages measuring up to $500 \times 200 "$." in size (Fig. 3). Many of the alveoli were lined by cuboidal cells which contained granules that gave a positive reaction with Perles' reagent. All stages were found to suggest a transition from flattened cells lining the alveoli to swollen, cuboidal cells which had ingested haemosiderin and then passed into the alveoli with many other similar cells to form foci of pulmonary haemosiderosis. The thickness of the alveolar walls was increased to $30 \mu$ as a result of distended pulmonary capillaries lying between the cuboidal cells described above. There was no ferrous impregnation of the elastica of the vessels or alveolar walls and no granulomatous giant cell reaction to the haemosiderin. In these lobes the small pulmonary blood vessels showed the characteristic changes of hypertensive pulmonary vascular disease. The muscular arteries (100 to $1,000 " \mu$ in external diameter) showed a thickened media. The mean medial thickness was $13.4 \%$ of the external diameter of the vessel and the mean area of muscle in cross section was $6.050 \mathrm{sq}$. microns. Corresponding figures for vessels

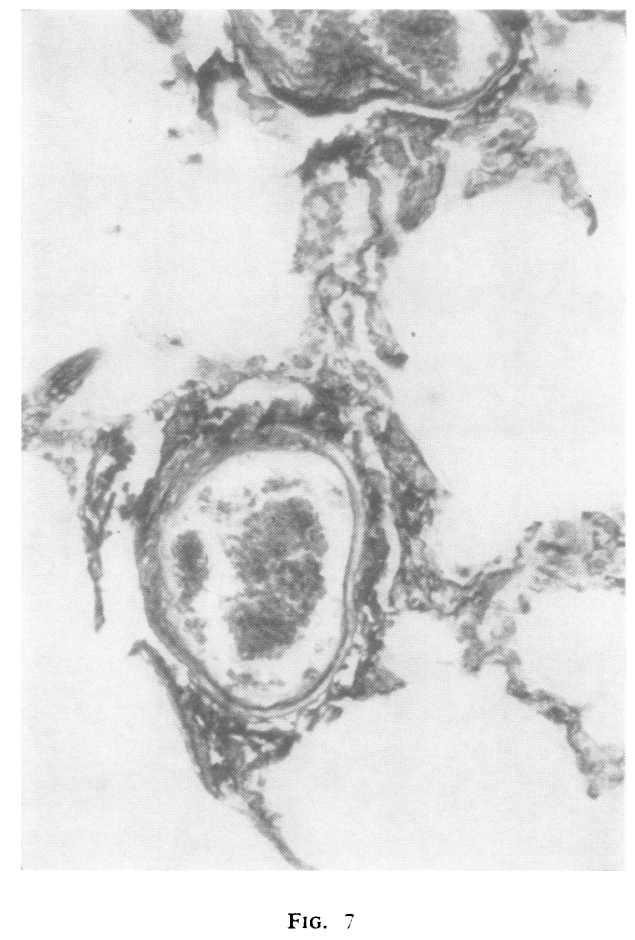

FIGS. 6 and 7.-.Stained to show elastic by the Lawson modification of the Weigert-Sheridan method and counterstained with Van Gieson's stain. Transverse sections of muscular pulmonary arteries from one of the lobes without pulmonary haemosiderosis. There is practically no intimal fibroelastosis. Compare with Fig. 4. Note that the media is much thinner. Fig. 6 about $360 \mu$ in diameter, 105. Fig. 7 about $160 \mu$ in diameter, 150 .

from the lower lobes of 16 controls, consisting of patients with no heart or lung disease, were $3.1^{\prime \prime}$. and 2,260 sq. microns. Proliferation of fibroelastic tissue in the intima severely reduced the lumina of many vessels (Fig. 4) and there was a thick fibrous adventitia. Pulmonary vessels below 100 ". in diameter were also abnormal, showing a muscular media with internal and external elastic laminae (Fig. 5). In the lower lobe of the normal lung, in sharp contradistinction to the lingula, vessels below 100 " in diameter with a muscular media are rarely found. In the present case the mean medial thickness in this class of vessel was $11.5^{\circ}$, of the external diameter. and the mean area of muscle in cross section was 815 sq. microns. The latter figure is much smaller than the mean value for the normal muscular pulmonary artery, indicating that these muscular vessels below $100 "$ in diameter are more likely to be pulmonary arterioles with abnormal development of muscle than constricted muscular pulmonary arteries. 100 to 1.000 ". in diameter. These hypertensive arterioles were numerous in the haemosiderotic lobes, but unlike the smaller pulmonary arteries showed practically no intimal fibroelastosis. The veins and 
venules, however, showed intimal fibrosis exceeding the normal age change. There was no arterial medial necrosis and no evidence of thin-walled collateral branches of muscular pulmonary arteries so frequently noted in the lung in cases of congenital heart disease with pulmonary arterial hypertension.

In sharp contrast, the small pulmonary vessels in the lobes not affected by gross pulmonary haemosiderosis were normal. In particular, the vessels below $100 \mu$ in diameter did not show a muscular media but were lined by a single elastic lamina and showed only the normal age change of intimal fibrosis. The mean medial thickness of the muscular pulmonary arteries was $2.9 \%$ of the external diameter of the vessel and the mean area of muscle in cross section was 1,707 sq. microns. These values are normal, the corresponding figures in the upper lobes of the 16 controls studied being $3.1 \%$ and $1,850 \mathrm{sq}$. microns. There was no intimal fibroelastosis (Figs. 6 and 7). The veins showed the age change of intimal fibrosis. There were many small foci of haemosiderosis and emphysema in these lobes.

\section{Discussion}

Many cardiac diseases are associated with severe pulmonary arterial hypertension to produce the clinico-pathological syndrome of hypertensive pulmonary vascular disease (Table II); others are characterized by diffuse myocardial disease and pulmonary venous hypertension to produce a clinical picture reminiscent of constrictive pericarditis (Table III). Mitral stenosis and left ventricular failure due to aortic disease or systemic hypertension may be associated with severely raised left auricular pressure and resultant pulmonary arterial hypertension (Tables II and V), but do not exhibit the pericarditis-like clinical picture as neither has a severe diffuse affection of the myocardium. However, in the present case diffuse myocardial fibrosis is associated with pulmonary arterial and venous hypertension and a clinical picture that represents a true fusion of the clinico-pathological syndromes resulting from the doubly elevated pressures (Table IV).

Clinico-pathological Syndrome Associated With Pulmonary Arterial Hypertension.Patients with pulmonary artery blood pressures chronically elevated to levels of the order of the systemic blood pressure form a distinct clinicopathological group termed hypertensive pulmonary vascular disease. This condition, which may complicate ventricular septal defect, patent ductus arteriosus, aorto-pulmonary septal defect, atrial septal defect, and mitral stenosis, or may occur as idiopathic pulmonary hypertension (Tables II and $\mathrm{V}$ ), presents a clinical picture that is domi-
TABLE I

NORMAL VALUES GIVEN FOR PULMONARY ARTERY AND " PULMONARY CAPILLARY" BLOOD PRESSURES IN PREVIOUS REPORTS

\begin{tabular}{|c|c|c|c|}
\hline Author & Year & $\begin{array}{c}\text { Pulmonary } \\
\text { Artery } \\
\text { Mean } \\
\text { Blood } \\
\text { Pressure } \\
\text { (mm. Hg) }\end{array}$ & $\begin{array}{l}\text { “Pulmonary } \\
\text { Capillary" or } \\
\text { Left Atrial (*) } \\
\text { Mean Blood } \\
\text { Pressure } \\
\text { (mm. Hg) }\end{array}$ \\
\hline $\begin{array}{l}\text { Lagerlöf and Werkö } \\
\text { Cournand } \\
\text { Dexter and others } \quad \ldots\end{array}$ & $\begin{array}{l}1948 \\
1950 \\
1950\end{array}$ & $\begin{array}{l}15 \\
13 \\
15\end{array}$ & ${ }_{9}^{5}(* 4)$ \\
\hline
\end{tabular}

nated by signs and symptoms characteristic of severe pulmonary arterial hypertension, which often mask the underlying cardiac anomalies. Members of this group, with the exception of mitral stenosis, exhibit only a slightly raised pulmonary capillary blood pressure not exceeding $20 \mathrm{~mm}$. Hg (Table II), the normal being in the region of $5 \mathrm{~mm}$. $\mathrm{Hg}$ (Table $\mathrm{I}$ ), as illustrated by reports of cardiac catheterization by various authors. All forms of hypertensive pulmonary vascular disease reflect the high pulmonary artery blood pressure in the form of definitive changes in the pulmonary vasculature, as illustrated in Figs. 3, 4, 6, and 7. These are atheroma in the elastic pulmonary arteries (more than $1,000 \mu$ in diameter), medial hypertrophy and intimal fibroelastosis in the muscular pulmonary arteries (100 to $1,000 \mu$ in diameter), and pulmonary arterioles (less than $100 \mu$ in diameter) with a distinct media and internal and external elastic laminae. Similarly throughout this group, the absence of severe pulmonary congestion and haemosiderosis suggests only a slight elevation of the pulmonary capillary pressure. Both pulmonary congestion and haemosiderosis appear to be more closely related to pulmonary venous than arterial hypertension (Heath and Whitaker, 1956b).

Clinico-Pathological Syndrome Associated With Pulmonary Venous Hypertension and Diffuse Myocarditis.-Balchum, McCord, and Blount (1956) have analysed the clinical and pulmonary haemodynamic pattern in diseases associated with diffuse myocardial changes; such diseases present the clinico-pathological syndrome of pulmonary venous hypertension with severe congestive cardiac failure. This group includes Fiedler's myocarditis, endomyocardial fibroelastosis, severe myocardial fibrosis secondary to coronary atherosclerosis, cardiac amyloidosis, the myocardial damage associated with scleroderma and possibly that found in Freidrich's ataxia, haemochromatosis and glycogen storage disease, and fatty and neoplastic infiltration of 
TABLE II

PULMONARY ARTERY AND " PULMONARY CAPILLARY" BLOOD PRESSURES IN SOME PREVIOUSLY REPORTED CASES OF HYPERTENSIVE PULMONARY VASCULAR DISEASE

\begin{tabular}{l|l|l|l|l}
\hline Disease & Authors & Year & $\begin{array}{c}\text { Pulmonary } \\
\text { Artery } \\
\text { Mean } \\
\text { Blood } \\
\text { Pressure } \\
\text { (mm. Hg) }\end{array}$ & $\begin{array}{c}\text { "Pulmonary } \\
\text { Capillary" } \\
\text { Mean } \\
\text { Blood } \\
\text { Pressure } \\
\text { (mm. Hg) }\end{array}$ \\
\hline
\end{tabular}

(A) Congenital heart disease

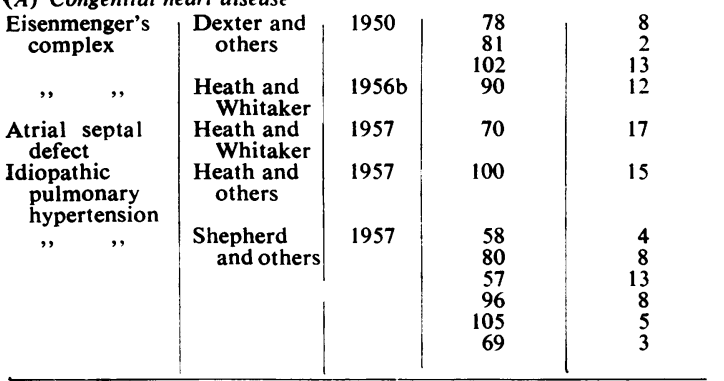

Pulmonary artery, 12 observations, mean $=82 \cdot 2 \mathrm{~mm}$. $\mathrm{Hg}$, range $=$ 57-105, S.D. $=23 \cdot 50$.

Pulmonary capillary, 12 observations, mean $=9.0 \mathrm{~mm}$. $\mathrm{Hg}$, range $=$ $2-17$, S.D. $=4 \cdot 65$.

(B) Mitral stenosis (no diffuse myocardial disease)

\begin{tabular}{|c|c|c|c|} 
Dexter and & 1950 & 78 & 40 \\
others & & 80 & 30 \\
& & 75 & 27 \\
& & 63 & 35 \\
Epps and & 1953 & 66 & 28 \\
Adler & & 75 & 30 \\
Whitaker & 1954 & 52 & 25 \\
and Lodge & & 70 & 35 \\
& & 78 & 33 \\
& & 80 & 34 \\
& & 81 & 36 \\
Heath and & $1956 \mathrm{~b}$ & 88 & 29 \\
Whitaker & & 64 & 36 \\
& & 66 & 37 \\
& & 69 & 42 \\
& & 74 & 37 \\
& & 82 & 30 \\
& & 90 & 34 \\
& & &
\end{tabular}

Pulmonary artery, 20 observations, mean $=73.6 \mathrm{~mm}$. Hg, range $=$ 52-90, S.D. $=8 \cdot 6$.

Pulmonary capillary, 20 observations, mean $=32.7 \mathrm{~mm}$. $\mathrm{Hg}$, range $=$ $25-42$, S.D. $=4 \cdot 8$.

(C) Cardiac failure (no diffuse myocardial disease)

\begin{tabular}{c|c|r}
$\begin{array}{c}\text { Dexter and } \\
\text { others }\end{array}$ & 1950 & 5 \\
& & 5 \\
& & 58 \\
& & 5
\end{tabular}

\begin{tabular}{l|l}
55 & 36 \\
48 & 32 \\
50 & 28 \\
58 & 35 \\
55 & 42
\end{tabular}

Pulmonary artery, 5 observations, mean $=53 \cdot 2 \mathrm{~mm}$. Hg, range $=$ 48-58, S.D. $=3.7$.

Pulmonary capillary, 5 observations, mean $=34.6 \mathrm{~mm} . \mathrm{Hg}$, range $=$ 28-42, S.D. $=4 \cdot 6$.

the myocardium. The clinical picture is like that of constrictive pericarditis with diminished amplitude of the radial pulse, pulsus paradoxus, congestive cardiac failure, and pulmonary congestion. The electrocardiogram shows changes similar to that of pericardial disease, while the
TABLE III

PULMONARY ARTERY AND " PULMONARY CAPILLARY" BLOOD PRESSURES IN SOME PREVIOUSLY REPORTED CASES OF PULMONARY VENOUS HYPERTENSION SYNDROME

\begin{tabular}{l|c|c|c|c}
\hline Disease & Authors & Year & $\begin{array}{c}\text { Pulmonary } \\
\text { Artery } \\
\text { Mean Blood } \\
\text { Pressure } \\
\text { (mm. Hg) }\end{array}$ & $\begin{array}{c}\text { "Pulmonary } \\
\text { Capillary" } \\
\text { Mean Blood } \\
\text { Pressure } \\
\text { (mm. Hg) }\end{array}$ \\
\hline $\begin{array}{l}\text { Endocardial } \\
\text { fibrosis }\end{array}$ & $\begin{array}{c}\text { Clark and } \\
\text { others } \\
\text { "Chronic } \\
\text { myocarditis" }\end{array}$ & 1956 & 32 & 25 \\
$\begin{array}{c}\text { Balchum } \\
\text { and others } \\
\text { Non-specific } \\
\text { myocarditis " }\end{array}$ & 1956 & 40 & 32 \\
and others & 1956 & 40 & 28 \\
\hline
\end{tabular}

Pulmonary artery, 3 observations, mean $=37 \mathrm{~mm} . \mathrm{Hg}$, range $=32 \rightarrow$ 40, S.D. $=6 \cdot 25$.

Pulmonary capillary, 3 observations, mean $=28 \mathrm{~mm}$. Hg, range $=25$ $\rightarrow 32$, S.D. $=5 \cdot 3$.

teleradiogram shows a globular cardiac silhouette with diminished cardiac activity on fluoroscopy. As in hypertensive pulmonary vascular disease, the findings at cardiac catheterization are most characteristic (Table III). Hansen, Eskildsen, and Götzsche (1951) originally described the intracardiac pressure tracings in constrictive pericarditis as showing atrial pressures with a maximum greater than normal and a saddle-shaped plateau. The ventricular pressure curves show a maximum that is not abnormal but a diastolic pressure that does not fall as low as normal and rises steeply in diastole to reach a high level which is maintained until systole begins. Similar pressure curves in this pulmonary venous hypertension group have been reported in myocardial fibrosis secondary to coronary atherosclerosis by Burwell and Robin (1954), in endocardial fibrosis by Clark, Valentine, and Blount (1956), and in non-specific myocarditis by Balchum and others (1956). The striking contrast to hypertensive pulmonary vascular disease lies in the slight elevation of pulmonary artery blood pressure which may approach levels of the order of $40 \mathrm{~mm}$. $\mathrm{Hg}$ (Table III), which is solely accounted for by the very elevated pulmonary capillary blood pressure, usually $25 \mathrm{~mm}$. $\mathrm{Hg}$ or over, even with an arterial pressure as low as $32 \mathrm{~mm}$. $\mathrm{Hg}$ (Table III). This is reflected in the histology of the lung, which shows normal blood vessels but pulmonary congestion and haemosiderosis.

The Present Case.-The present case illustrates the co-existence of these two clinicopathological syndromes (Table IV). So far as we are aware the association of diffuse myocardial fibrosis with pulmonary arterial hypertension has never been reported, although in the first report of endomyocardial fibroelastosis by Bedford and Konstam (1946) a raised pulmonary 
TABLE IV

PULMONARY ARTERY AND " PULMONARY CAPILLARY" BLOOD PRESSURES IN SOME PREVIOUSLY REPORTED CASES OF DISEASES WITH SEVERE HYPERTENSION IN BOTH PULMONARY ARTERIES AND VEINS

\begin{tabular}{c|c|c|c|c}
\hline Disease & Author & Year & $\begin{array}{c}\text { Pulmonary } \\
\text { Artery } \\
\text { Blood } \\
\text { Pressure } \\
\text { (mm. Hg) }\end{array}$ & $\begin{array}{c}\text { "Pulmonary } \\
\text { Capillary" } \\
\text { Mean Blood } \\
\text { Pressure } \\
\text { (mm. Hg) }\end{array}$ \\
\hline Mitral stenosis & $\begin{array}{c}\text { Whitaker } \\
\text { and Lodge }\end{array}$ & 1954 & $\mathbf{8 8 \text { (mean) }}$ & 36 \\
$\begin{array}{c}\text { Myxoma of left } \\
\text { atrium } \\
\text { an Buchem } \\
\text { and Eerland } \\
\text { dialu fibrosis } \\
\text { This case } \\
\text { mastiastinal occlud- } \\
\text { ing pulmonary } \\
\text { veins }\end{array}$ & $\begin{array}{c}\text { Edwards } \\
\text { and } \\
\text { Burchell }\end{array}$ & 1957 & 12050 & 40 \\
\hline
\end{tabular}

artery blood pressure was suggested by their description of a much accentuated second sound in the pulmonary area and a prominent pulmonary artery and conus in the teleradiogram. The relation of this case to other diseases showing pulmonary venous and/or arterial hypertension with pulmonary congestion and haemosiderosis and/or hypertensive changes in the pulmonary vasculature is shown in Table $\mathrm{V}$.

Pulmonary arterial hypertension in the present patient was probably related to the raised left auricular blood pressure. Other diseases with elevated pressure in both the pulmonary arteries and veins are mitral stenosis (Table II), left ventricular failure following aortic stenosis or systemic hypertension (Dexter, Dow, Haynes, Whittenberger, Ferris, Goodale, and Hellems, 1950 ; Cournand, 1950), myxoma of the left atrium (Van Buchem and Eerland, 1957), and obstruction of pulmonary veins by a mediastinal mass (Edwards and Burchell, 1951). Dexter and others (1950) realized that elevated pulmonary capillary pressures were consistently found in patients with mitral stenosis and in those with left ventricular failure. When the "pulmonary capillary" pressure rose to values of about $25 \mathrm{~mm}$. $\mathrm{Hg}$, the pressure in the pulmonary artery rose proportionately but the pulmonary artery-pulmonary capillary pressure gradient and the pulmonary arteriolar resistance remained normal. With "pulmonary capillary" pressures in excess of $25 \mathrm{~mm}$. $\mathrm{Hg}$, pressure in the pulmonary artery rose disproportionately, the artery-capillary pressure gradient widened, and the pulmonary arteriolar resistance increased on occasions to 20 or more times the normal value. Such clinical observations suggest that in man a pressor reflex may exist between the left atrium and pulmonary arteries, as suggested by the experimental work on animals by Ferri, Rovati, Panesi, Romanelli, and Righini (1956), Kleinerman, Chitescu, Busu, Enescu, and Lupu (1956), and Rovati, Ferri, Romanelli, Panesi, and Righini (1956). These workers have shown that experimental occlusion of the pulmonary veins in animals may induce reflexly a rise in pulmonary artery blood pressure. However, only a percentage of patients, apparently lower in diffuse myocarditis than in mitral stenosis, with a raised left auricular blood pressure develop pulmonary arterial hypertension, so that the problem appears to be more complex than a straightforward causal relationship between the two. Conditions similar to those produced in the animal experiments mentioned were found by Edwards and Burchell (1951) in a woman of 26 years who had severe acquired venous stasis in all except one pulmonary lobe due to a mediastinal mass. Cardiac catheterization demonstrated pulmonary arterial hypertension and a normal pulmonary blood flow. The

TABLE V

CARDIAC DISEASES ASSOCIATED WITH RAISED BLOOD PRESSURE IN THE LUNG

\begin{tabular}{|c|c|c|c|c|}
\hline & $\begin{array}{c}\text { Severe Pulmonary Arterial Hyper- } \\
\text { tension with Normalor Only Slightly } \\
\text { Elevated Blood Pressure in the } \\
\text { Pulmonary Veins }\end{array}$ & $\begin{array}{l}\text { Severe Pulmonary Arterial } \\
\text { Hypertension with Severe } \\
\text { Pulmonary Venous } \\
\text { Hypertension }\end{array}$ & $\begin{array}{l}\text { Slight to Moderate Pul- } \\
\text { monary Arterial Hyperten- } \\
\text { sion with Pulmonary } \\
\text { Venous Hypertension }\end{array}$ & $\begin{array}{l}\text { Normal or Slightly Elevated } \\
\text { Pulmonary Atrery Blood Pressure } \\
\text { with Severe Pulmonary } \\
\text { Venous Hypertension }\end{array}$ \\
\hline $\begin{array}{l}\text { Without valvula } \\
\text { lesions or } \\
\text { septal defects }\end{array}$ & Idiopathic pulmonary hypertension & $\begin{array}{l}\text { Some cases of diffuse myocardial } \\
\text { disease associated with pul- } \\
\text { monary arterial hypertension, } \\
\text { as in the present instance } \\
\text { Some cases of myxoma of the } \\
\text { left atrium. Mediastinal } \\
\text { masses occluding pulmonary } \\
\text { veins }\end{array}$ & $\begin{array}{l}\text { Left ventricular failure due } \\
\text { to systemic hypertension }\end{array}$ & $\begin{array}{l}\text { Some cases of Fiedler's myocarditio } \\
\text { endomyocardial fibroelastosis, mye } \\
\text { cardial fibrosis due to coronage } \\
\text { artery disease, scleroderma heag } \\
\text { disease. Possibly haemochromato } \\
\text { sis, van GGierke's disease, Frieg } \\
\text { reich's ataxia, fatty and neoplastic } \\
\text { infiltration of the heart }\end{array}$ \\
\hline $\begin{array}{l}\text { With valvular } \\
\text { lesions or } \\
\text { septal defects }\end{array}$ & $\begin{array}{|cc|}\text { Eisenmenger's complex, } & \text { with } \\
\text { atrial septal defect, } \\
\text { ventricular septal de- } \\
\text { fect, patent ductus } & \text { arteriary } \\
\text { arteriosus, aorto-pul- } & \text { hyperten- } \\
\text { monary septal defect } & \text { sion } \\
\text { monal } & \end{array}$ & Many cases of mitral stenosis & $\begin{array}{l}\text { Some cases of mitral steno- } \\
\text { sis. Left ventricular } \\
\text { failure due to aortic valve } \\
\text { disease }\end{array}$ & 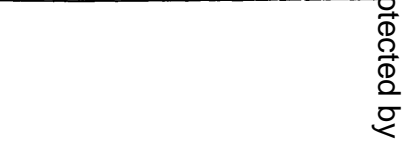 \\
\hline
\end{tabular}


lobe without significant venous stenosis had normal arterioles and small arteries, but in the remaining lobes there were severe occlusive vascular changes similar to those seen in some cases of mitral stenosis. In the present patient too, hypertensive changes in the small pulmonary vessels occurred only in those lobes with severe venous hypertension, as shown by pulmonary haemosiderosis. It appears that in cases with elevated pressure both in arteries and in veins the obstructive arterial lesions are directly related to pulmonary venous hypertension, which may exert its effect by inducing a reflex vasoconstriction in the pulmonary arteries, comparable to that produced experimentally in animals. The level of pulmonary arterial blood pressure alone does not appear to be directly responsible for the vascular changes, for, although there was pulmonary arterial hypertension, as proved by cardiac catheterization, in the lobes free from gross pulmonary haemosiderosis and severe venous hypertension in both the present case and that reported by Edwards and Burchell, there were no arterial changes in those lobes. In this connexion O'Neal, Thomas, and Hartroft (1955) have suggested that small pulmonary vessels below $100 \mu$ in diameter with a distinct muscular media, the hall-mark of hypertensive pulmonary vascular disease, are vasoconstricted muscular arteries rather than muscularized pulmonary arterioles.

\section{SUMMARY}

The clinical and pathological features of a fatal case of diffuse myocardial fibrosis are described.
The pulmonary histology represented a fusion of the patterns produced by hypertension in the pulmonary veins and arteries respectively.

We wish to thank Dr. C. E. Davies, Dr. J. L. Edwards, and Dr. T. Lodge for allowing us to report this case. The cardiac catheterization was performed at the Regional Cardiovascular Centre, Sheffield, under the direction of Dr. James W. Brown.

\section{REFERENCES}

Balchum, O. J., McCord, M. C., and Blount, S. G. (1956). Amer Heart J., 52, 430.

Bedford, D. E., and Konstam, G. L. S. (1946). Brit. Heart J., 8, 236. Best, P. B., and Heath, D. J. (1957). J. Path. Bact., in press.

Burwell, C.'S., and Robin, E. D. (1954). Trans. Ass. Amer. Phys., 67,67 .

Clark, G. M., Valentine, E., and Blount, S. G. (1956). New Engl. J. Med., 254, 349.

Cournand, A. (1950). Circulation, 2, 641.

Dexter, L., Dow, J. W., Haynes, F. W., Whittenberger, J. L., Ferris, B. G., Goodale, W. T., and Hellems, H. K. (1950). J. clin. Invest., 29, 602 .

Edwards, J. E., and Burchell, H. B. (1951). Arch. intern. Med., 87, 372 .

Epps, R. G., and Adler, R. H. (1953). Brit. Heart J., 15, 298.

Ferri, F., Rovati, V., Panesi, M., Romanelli, R., and Righini, E. (1956). Abstracts of Papers, Second European Congress of Cardiology, p. 103.

Hansen, A. T., Eskildsen, P., and Götzsche, A. (1951). Circulation, 3,881 .

Heath, D., and Whitaker, W. (1956a). Ibid., 14, 323.

- (1956b). J. Path. Bact., 72, 531. (1956b). J. Path. Bact., 72, 531.

- and Brown, J. W. (1957). Ibid., 19, 83.

Kleinerman, L., Chitescu, T., Busu, J., Enescu, N., and Lupu, A. (1956). Abstracts of Papers, Second European Congress of Cardiology, p. 146.

Lagerlöf, H., and Werkö, L. (1948). Acta physiol. scand., 16, 75.

O'Neal, R. M., Thomas, W. A., and Hartroft, P. M. (1955). A.M.A. Arch. Path., 60, 267.

Rovati, V., Ferri, F., Romanelli, R., Panesi, M., and Righini, E. (1956). Abstracts of Papers, Second European Congress of Cardiology, p. 220.

Shepherd, J. T., Edwards, J. E., Burchell, H. B., Swan, H. J. C., and Wood, E. H. (1957). Brit. Heart J., 19, 70 .

Van Buchem, F. S. P., and Eerland, L. D. (1957). Dis. Chest, 31, 61. Whitaker, W., and Lodge T. (1954). J. Fac. Radiol. (Lond.), 5, 182. 